\title{
Coal mining in Kuzbass and new technologies for revegetation of dumps
}

\author{
Aleksandr Kopytov ${ }^{1 *}$, Oleg Kupriyanov ${ }^{2,3}$, Yury Manakov, and Andrey Kupriyanov ${ }^{3}$ \\ ${ }^{1}$ T.F. Gorbachev Kuzbass State Technical University, Vesennyaya 28, Kemerovo, the Russian \\ Federation, 650000 \\ ${ }^{2}$ Kemerovo Branch of the Institute of Computational Technologies of SB RAS, Kemerovo \\ ${ }^{3}$ Federal Research Center for Coal and Coal Chemistry of SB RAS, Leningradskiy 10, Kemerovo, \\ the Russian Federation, 650000 \\ ${ }^{4}$ Siberian Federal Scientific Center of Agrobiotechnology of RAS
}

\begin{abstract}
During the period of coal mining in Kuzbass, about 9 billion tons of coal were mined, which is $16 \%$ of all in-place reserves of coal in Kuzbass. In 2020, coal production amounted to 220.7 million tons, including 164.4 million tons of open pit mining, which is $74 \%$ of the total. The negative side of an increase in the share of open pit coal mining is an increase in the area of disturbed lands, which currently reaches 150 thousand hectares. To restore the biological diversity of dumps, a nature-like technology has been developed for revegetation of dumps, which consists in applying a $15 \mathrm{~cm}$ thick loam layer to the dump and introducing a grass seed mixture containing seeds of steppe plants. For six years, a stable, self-perpetuating permanent nature-like community is formed, numbering $30-40$ species of steppe plants.
\end{abstract}

\section{Indroduction}

The Kuznetsk coal basin is one of the largest deposits in the world, which is located in the south of Western Siberia, mainly in the Kemerovo region - Kuzbass (Fig. 1).

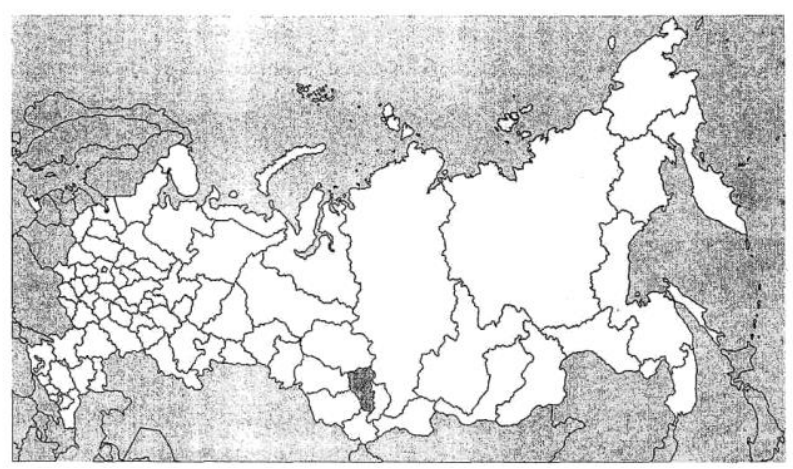

Fig. 1. Kuzbass on the map of Russia

*Corresponding author: kai.spssh@kuzstu.ru 
During the period of coal mining in Kuzbass, about 9 billion tons of coal were mined, which is $16 \%$ of all in-place reserves of coal in Kuzbass. It should be noted that 3.96 billion tons have been produced over the past 20 years (Table 1). At the same time, from 2000 to 2020, the volumes of coal production in Russia increased 1.6 times, in Kuzbass 2.2 times and reached a record 255.3 million tons in 2018 , almost $60 \%$ of the total in Russia [1]. Due to a decrease in the demand for coal in Europe and the limited possibilities of transporting it to the East, the volumes of coal production in the Kemerovo Region in 2020 decreased to 220.7 million tons (by 11.8\%). Despite this, opencast coal production in the region increased to 164.4 million tons, which is $74 \%$ of the total. Kuzbass will remain the leading coal-mining region of Russia for a long time due to the presence of large volumes of proven reserves of high-quality coal that meet market requirements, the state of infrastructure, mining conditions and importance in the fuel and energy market of the world [2]. Therefore, President Vladimir Putin has set the task of expanding Russia's presence in the global coal market by doubling the volume of supplies to the east. To this end, at a meeting in Kemerovo on 03/06/2021, the Chairman of the Government of the Russian Federation V.M. Mishustin outlined measures to accelerate the development of the Eastern landfill, as a result of which the volume of coal transportation from Kuzbass should be increased by $30 \%$ in 2 years.

The negative side of the Kuzbass coal industry development and an increase in the share of opencast coal mining is an increase in the area of disturbed lands, in which the general profile of the earth's surface completely changes, biological diversity is completely or partially destroyed [3]. At present, only dumps and open pits in Kuzbass occupy an area of about 150 thousand hectares (Fig. 2).

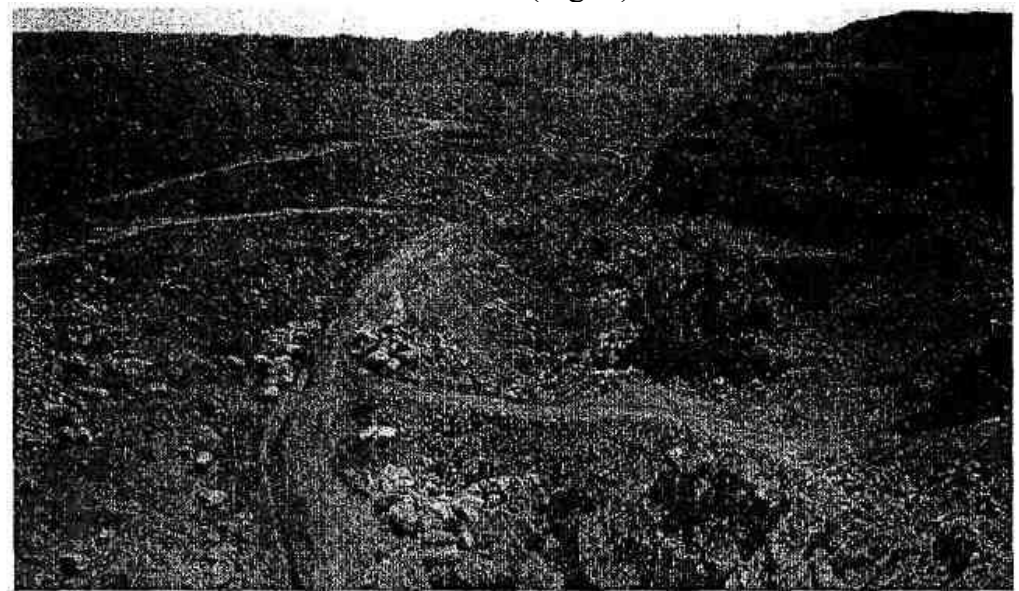

Fig. 2. Opencast coal mine

Table 1. Coal production in Kuzbass for the period 1860-2020, million tons

\begin{tabular}{|c|c|c|c|c|c|c|c|}
\hline 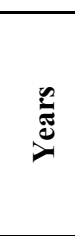 & 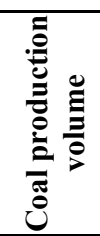 & 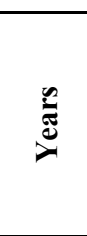 & 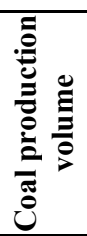 & 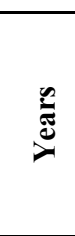 & 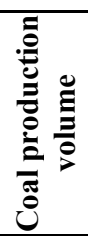 & $\underset{\varpi}{\varpi}$ & 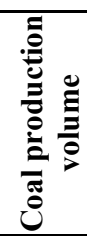 \\
\hline 1860 & 0.001 & 1945 & 28.8 & 1994 & 99.0 & 2011 & 192.0 \\
\hline 1870 & 0.005 & 1950 & 36.8 & 1995 & 99.3 & 2012 & 201.5 \\
\hline
\end{tabular}




\begin{tabular}{|l|c|c|c|c|c|c|c|}
\hline 1880 & 0.008 & 1955 & 56.5 & 1996 & 95.0 & 2013 & 203.0 \\
\hline 1885 & 0.013 & 1958 & 72.1 & 1997 & 93.9 & 2014 & 211.0 \\
\hline 1890 & 0.020 & 1965 & 96.3 & 1998 & 97.6 & 2015 & 215.8 \\
\hline 1895 & 0.023 & 1969 & 109.5 & 1999 & 108.8 & 2016 & 227.4 \\
\hline 1900 & 0.080 & 1970 & 121.0 & 2000 & 114.9 & 2017 & 241.5 \\
\hline 1905 & 0.4 & 1975 & 137.6 & 2001 & 127.7 & 2018 & 255.3 \\
\hline 1913 & 0.73 & 1980 & 144.9 & 2002 & 131.7 & 2019 & 251.1 \\
\hline 1915 & 1.1 & 1985 & 146.0 & 2003 & 132.0 & 2020 & 220.7 \\
\hline 1917 & 1.3 & 1988 & 159.4 & 2004 & 159.0 & & \\
\hline 1926 & 1.7 & 1990 & 150.0 & 2005 & 167.2 & & \\
\hline 1928 & 2.4 & 1991 & 124.0 & 2008 & 184.5 & & \\
\hline 1930 & 3.5 & 1992 & 120.0 & 2009 & 181.3 & & \\
\hline 1940 & 2.1 & 1993 & 106.0 & 2010 & 185.5 & & \\
\hline
\end{tabular}

Until the second half of the 20th century, the issues of soil fertility recovery, restoration of biological diversity of disturbed lands were scarcely dealt with. The first observations and experiments of V.V. Tarchevsky [4] became a landmark event. The most important stage in the restoration of disturbed lands in the USSR and Kuzbass was the study of reclamation by forest planting conducted by L.P. Barannik [5] (1978), and reclamation by agriculture carried out by AP Zakharov [6]. By the end of the 20th century, the basic principles and directions of the biological stage of reclamation were formed as a set of techniques that increase the fertility and economic value of reclaimed lands. Experimental studies carried out by soil scientists in Kuzbass for 40 years show that it is impossible to completely restore the lost soil functions in the foreseeable period. The maximum result obtained on the experimental sites is $90 \%$, and the average value of fertility of reclaimed lands is about 30\% [7]. Until the end of the 20th century, the paradigm of the biological stage of reclamation was not aimed at restoring biological diversity, since the formation of plant communities in territories subjected to catastrophic changes obeys the general laws of primary succession [9-12], which require an extremely long period.

In 1992 in Rio de Janeiro, at the UN Conference on Environment and Development at the level of heads of government of fifty countries, it was announced that the greatest value that humankind must preserve for future generations is biological diversity. The relevant provisions have been enshrined in the Convention on Biological Diversity (CBD). The strategic plan of the CBD envisages "the desire of the world community to ensure the conservation, restoration and wise use of biodiversity by 2050 ..." [8].

It became necessary to develop new nature-like technologies for restoring the biological diversity of lands disturbed by open-pit coal mining. At the same time, two problems became apparent: restoration of meadow-steppe ecosystems, which scarcely recover with natural overgrowing of dumps and rational use of the removed layer of fertile soil when preparing sites at coal mines and dumps. 
In 2014, at the Vinogradovsky dump of PJSC Kuzbass Fuel Company, a testing ground was laid for the restoration of meadow-steppe ecosystems. The main task was to create a nature-like community in the dump. The technical stage consisted in leveling the dump consisting of mudstones, siltstones and sandstones. A part of the dump was covered with overburden loam with a layer of $15 \mathrm{~cm}$ and the soil from the walls formed during the construction of open pit mine with a layer of up to $15 \mathrm{~cm}$, part of the dump remained without improvement. The grass seed mixture for the revegetation was harvested in the steppe ecotopes of the Bachat hills, located outside the mining allotment and represented by large-sod and meadow-steppe communities. The grass seed mixture was harvested at the beginning and at the end of summer (June-August), ground and introduced to the testing ground in October, before the formation of snow cover (Fig. 3). The dynamics of the floristic composition was observed from 2015 to 2020.

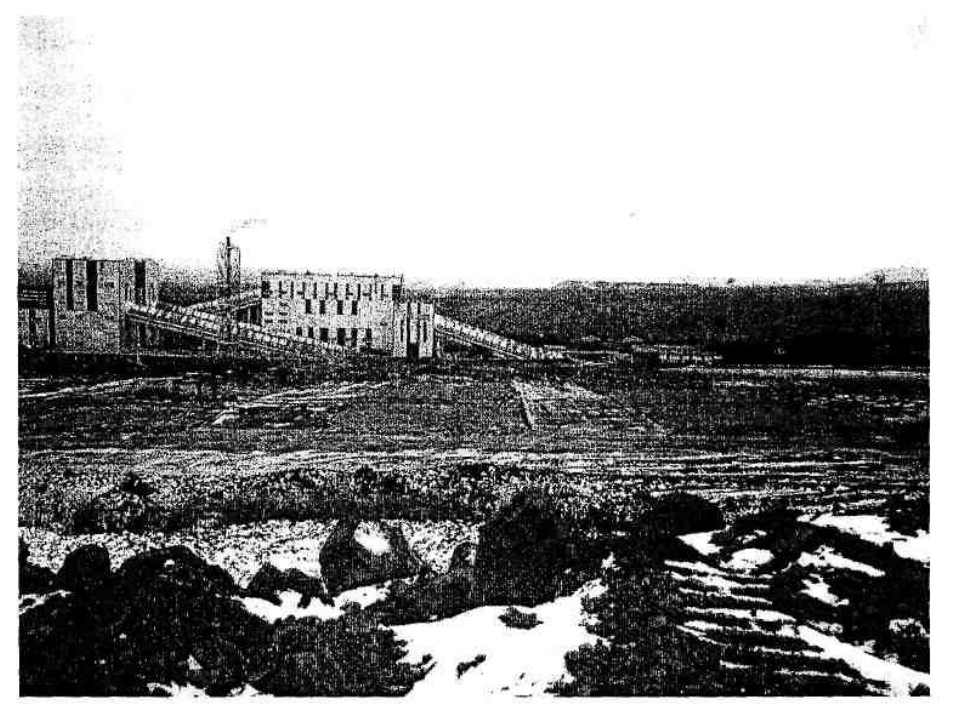

Fig. 3. Experimental testing ground for the restoration of meadow-steppe communities on the dump in 2014

For six years, in the variant with the application of loams, a stable, self-perpetuating permanent nature-like community was formed, reproduced according to the model of the original natural communities that previously existed in the given territory. It is characterized by the presence of 30-40 zonal meadow-steppe species, including the following typical steppe species: Artemisia austriaca, Dianthus versicolor, Elisanthe noctiflora, Galium verum, Goniolimon speciosum, Gypsophila patrinii, Hedysarum gmelinii, Medicago falcata, Seseli ledebourii, Stipa capillata (Fig. 4). 


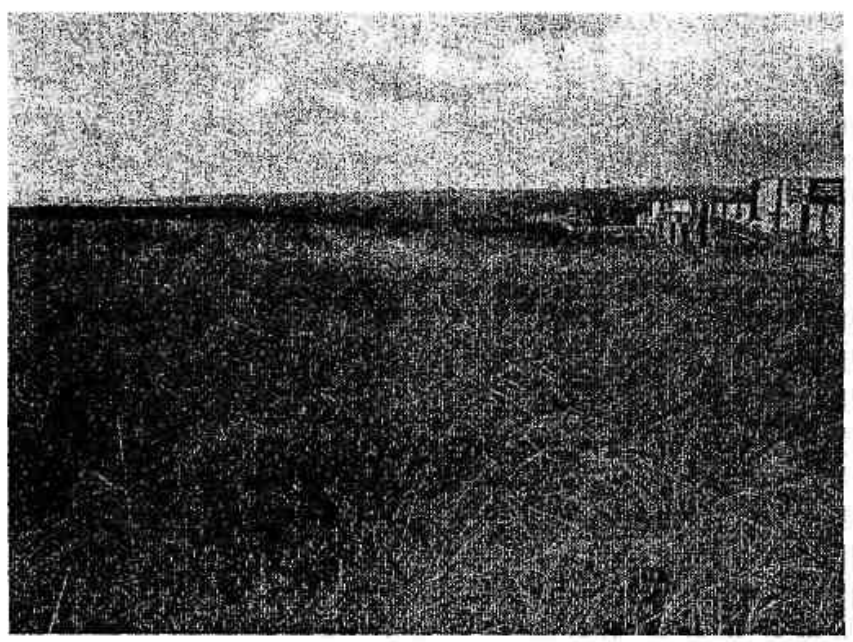

Fig. 4. Restored large turf steppe dominated by esparto grass (Stipa capillata), 2019

The application of soil from the walls formed during the construction of the open pit leads within four years to the intensive development of Elytrigia repens and the suppression of the development of meadow steppe plants. Weed species Bunias orientalis, Galeopsis bifida, Lactuca serriola, Salsola collina, Viola arvensis dominated in the herbage, meadow-steppe species were represented by Artemisia austriaca, Goniolimon speciosum, Heteropappus altaicus. In the control site, where the grass-seed mixture was applied to the unimproved surface of the dump, the stages of syngenesis took place in a known order and in the sixth year were represented by overgrown bush communities [12].

An important isue for the formation of nature-like communities is the quality of the applied substrate. The use of stored soils for biological reclamation purposes is regulated by a large number of recommendations and instructions [13]. With long-term storage of soil in piles, its properties change significantly [14]. It is biologically infected with weeds and, above all, with the rhizomes of Elytrigia repens, which complicates the creation of nature-like communities. It is hardly possible to use this soil for grounding, since the fight against weeds will negate all the benefits from the use of this agricultural technique. The use of quaternary loams and overburden clays provides faster formation of nature-like communities with high productivity.

\section{References}

1. A. Kopytov, S. Shaklein, Economics and organization of industrial production, 11, 76 (2018)

2. V. Potapov, V. Mazikin, E. Schastlivtsev, N. Vashlaeva. Geoecology of coal-mining regions of Kuzbass (Science, Novosibirsk, 2005)

3. A. Kopytov, A. Kupriyanov, Coal, 11, 89 (2019)

4. V. Tarchevskiy, About a new branch of industrial botany knowledge. Plant and industrial pollution (Sverdlovsk, 1967)

5. L. Barannik, Ecological justification and experience of biological reclamation in anthropogenic areas in Kuzbass. Methods for studying athropogenic biogeocenoses (Moscow, 1978)

6. A. Zakharov, Siberian Bulletin of Agricultural Science, 3, 29 (2003) 
7. I. Gadzhiev, V. Kurachev, V. Adokhanov, Strategy and prospects for solving the problems of land reclamation (Novosibirsk, 2001)

8. Convention on Biological Diversity (1992)

F. Clements, Plant Succession and Indicators (New York, 1928)

9. J. Grime, J. Hodgson, R. Hunt, Comparative plant ecology: a functional approach to common British species (Landon, Unwin Hyman, 1988)

10. V. Mirkin, Theoretical foundations of modern phytocenology (Science, Moscow, 1985)

11. A. Kupriyanov, Yu. Morsakova, Siberian ecological journal, 2, 255 (2008)

12. A. Klopotovskiy, Bulletin of agricultural science, 5, 21 (1981)

13. GOST 17.5.3.04-83. Protection of Nature. Earth. General requirements for land reclamation

14. N. Kozhevnikov, A. Zaushintsina, Bulletin of Kemerovo State University, 1, 10 (2015) 